Nina OgińsKa-BuliK

Uniwersytet Łódzki

Wydział Nauk o Wychowaniu

Instytut Psychologii

Zakład Psychologii Zdrowia

91-433 Łódź, ul. Smugowa 10/12

e-mail:noginska@uni.lodz.pl

\title{
RUMINACJE A POTRAUMATYCZNY WZROST U RATOWNIKÓW MEDYCZNYCH
}

\begin{abstract}
Abstrakt. Przedstawiciele służb ratowniczych narażeni są na doświadczanie zdarzeń o charakterze traumatycznym w związku z wykonywaną pracą. Celem badań było ustalenie roli ruminacji w występowaniu pozytywnych zmian potraumatycznych. Badaniami objęto 120 ratowników medycznych, spośród których 85 (55 mężczyzn i 30 kobiet) potwierdziło wystąpienie w ostatnich 5 latach przynajmniej jednego zdarzenia traumatycznego $\mathrm{w}$ związku z wykonywaną pracą. Wiek badanych mieścił się w granicach 25-61 lat $(\mathrm{M}=38,07, \mathrm{SD}=9,61)$. W badaniach wykorzystano polskie wersje standaryzowanych narzędzi, tj. Inwentarz Potraumatycznego Rozwoju oraz Inwentarz Ruminacji o Negatywnym Zdarzeniu. Badani ratownicy medyczni ujawnili niski poziom potraumatycznego wzrostu oraz niskie nasilenie ruminacji, tak natrętnych, jak i refleksyjnych. Spośród dwóch analizowanych rodzajów ruminacji jedynie refleksyjne okazały się predyktorami potraumatycznego wzrostu i wszystkich jego czynników. Ruminacje refleksyjne pełnią istotną - choć słabą - rolę w występowaniu pozytywnych następstw doświadczonej traumy.
\end{abstract}

Słowa kluczowe: zdarzenia traumatyczne, potraumatyczny wzrost, ruminacje, ratownicy medyczni.

\section{WPROWADZENIE}

\section{DOŚWIADCZANIE TRAUMY PRZEZ PRACOWNIKÓW SŁUŻB RATOWNICZYCH}

Praca $w$ służbach ratowniczych, a zwłaszcza w ratownictwie medycznym, wiąże się $\mathrm{z}$ wysokim poziomem stresu, w tym stresu o charakterze traumatycznym. Klasyfikacja DSM-IV zakładała, że z wydarzeniem traumatycznym mamy do czynienia, gdy

1) dana osoba przeżyła, była świadkiem lub została skonfrontowana ze zdarzeniem lub zdarzeniami związanymi ze śmiercią lub zagrożeniem życia bądź poważnym zranieniem, zagrożeniem fizycznej integralności własnej czy innych ludzi, 
2) reakcje tej osoby charakteryzował intensywny strach, poczucie bezradności lub zgrozy (APA, 1994; por. także: Lis-Turlejska, 2009).

W DSM-V (APA, 2013; por. także: Steuden, Janowski, 2016) usunięto kryterium subiektywnej reakcji emocjonalnej, obecne w poprzedniej klasyfikacji, kładąc nacisk na rodzaj doświadczonego stresora. W DSM-V uwzględniono - oprócz bezpośredniego doświadczenia urazowego, bycia bezpośrednim świadkiem takiego wydarzenia - doświadczenia pośrednie (np. poprzez wiadomość o śmierci bliskiej osoby), wielokrotne lub ekstremalne narażenie na awersyjne szczegóły wydarzeń urazowych, zwykle występujących podczas wykonywania czynności zawodowych, co dotyczy również służb ratowniczych.

Rozpowszechnienie zdarzeń traumatycznych wśród przedstawicieli służb ratowniczych jest dość wysokie. Wskazują na to wyniki badań przeprowadzonych przez Ogińską-Bulik (2015) w 720-osobowej grupie, obejmującej strażaków, policjantów i ratowników medycznych. 79,2\% badanych potwierdziło wystąpienie doświadczenia traumatycznego w związku z wykonywaną pracą.

Występowanie zdarzeń traumatycznych $\mathrm{w}$ grupie ratowników medycznych wykazano m.in. w badaniach australijskich (Kirby i in., 2011), brytyjskich (Clohessy, Ehlers, 1990) i kanadyjskich (Regehr i in., 2002). Badania przeprowadzone w Szwecji (Jonsson i in., 2003) dostarczyły danych wskazujących, że blisko $62 \%$ badanych ratowników zatrudnionych w zespołach pogotowia ratunkowego doświadczyło traumatycznego zdarzenia podczas swojej pracy. Z badań przeprowadzonych przez Instytut Medycyny Pracy w Łodzi wynika, że w trakcie pełnienia obowiązków służbowych $72 \%$ pracowników pogotowia ratunkowego doświadczyło zdarzenia traumatycznego co najmniej jeden raz, a 64\% - dwa razy i więcej (Dudek, 2003; Koniarek, 1997).

\section{NASTĘPSTWA DOŚWIADCZANYCH ZDARZEŃ TRAUMATYCZNYCH - POTRAUMATYCZNY WZROST}

Ekspozycja na traumę wiąże się z ryzykiem wystąpienia różnych negatywnych konsekwencji, wśród których wyróżnia się przede wszystkim zaburzenie stresu ostrego (Acute Stress Disorder - ASD) oraz zespół stresu pourazowego (Posttraumatic Stress Disorder - PTSD).

PTSD występuje u ok. 10-20\% ratowników medycznych (Andersen i in., 2007; Jonsson i in., 2003). W Polsce ten odsetek jest nieco niższy. Z raportu opracowanego przez Instytut Medycyny Pracy w Łodzi wynika, że prawie 5\% pracowników wyjazdowych pogotowia ratunkowego narażonych na zdarzenia traumatyczne w związku z wykonywaną pracą ujawniło PTSD (Koniarek, 1997).

Doświadczenie zdarzenia traumatycznego może pociągać za sobą nie tylko negatywne, lecz także pozytywne następstwa w postaci potraumatycznego wzrostu (Posttraumatic Growth - PTG). Potraumatyczny wzrost oznacza występowanie 
pozytywnych zmian, które pojawiają się w wyniku podejmowanych prób poradzenia sobie z doświadczeniami traumatycznymi. Obejmują one zmiany w percepcji siebie, w relacjach interpersonalnych i filozofii życiowej (Tedeschi, Calhoun, 1996, 2004).

Potraumatyczny wzrost jest czymś więcej niż tylko powrotem do stanu równowagi po przeżytym zdarzeniu. Jednostka w wyniku doświadczonej sytuacji przechodzi pewnego rodzaju transformację i uzyskuje wyższy niż przed traumą poziom funkcjonowania. Wzrost po traumie nie oznacza, że przeżycie traumy jest czymś pozytywnym czy koniecznym dla dokonania istotnych zmian w życiu. Nie jest też utożsamiany z poczuciem szczęścia, lecz jest szansą na bardziej sensowne i wartościowe życie. Nie należy także oczekiwać, że każda osoba, która przeżyła traumę, doświadczy wzrostu, lub że jest to niezbędny warunek pełnego powrotu do zdrowia po przeżyciu traumy. To nie trauma - jak podkreślają Tedeschi i Calhoun $(1996,2004)$ - prowadzi do wzrostu, lecz podejmowana przez jednostkę aktywność mająca na celu poradzenie sobie z kryzysem.

Z badań przeprowadzonych wśród amerykańskich pracowników służb ratowniczych, obejmujących strażaków, policjantów i ratowników medycznych, wynika, że $87 \%$ spośród nich wykazało co najmniej jedną pozytywną zmianę w wyniku doświadczonej sytuacji traumatycznej, jaką był udział w ratowaniu ludzi po ataku terrorystycznym 11 września 2001 roku w Nowym Jorku. Zmiany te przejawiały się w postaci osobistego wzrostu i doceniania życia, poczucia bliższych relacji z innymi, a szczególnie ze współpracownikami, poczucia uznania w miejscu pracy, a także przygotowania się na przyszłe traumatyczne wydarzenia (Melersky, 2008).

Występowanie pozytywnych zmian po traumie potwierdzono w badaniach kanadyjskich i australijskich zespołów pogotowia ratunkowego (Gray, 2008). Podobnie w polskich badaniach pracowników służb ratowniczych, obejmujących strażaków, policjantów i ratowników medycznych (Ogińska-Bulik, 2015), u prawie 26\% stwierdzono wysoki poziom wzrostu ( $40 \%$ - niski i ok. $34 \%$ - przeciętny).

\section{RUMINACJE A WYSTĘPOWANIE WZROSTU PO TRAUMIE}

Przeżycie zdarzenia traumatycznego wywiera istotny wpływ na sposób myślenia jednostki o tym zdarzeniu, a także o samej sobie i otaczającej ją rzeczywistości. Tego typu doświadczenie uruchamia aktywność jednostki mającą na celu poznawcze przetworzenie traumy. To zaangażowanie poznawcze, polegające na dokładnej i głębokiej analizie znaczenia doświadczonego wydarzenia dla życia człowieka, jest - jak zauważają Tedeschi i Calhoun (2004) - istotnym czynnikiem, który może prowadzić do wzrostu. W procesie zaangażowania poznawczego szczególną rolę odgrywa ruminowanie.

Ruminowanie nie jest pojęciem jednoznacznym. Najczęściej jest rozumiane jako rozważanie, rozmyślanie czy ,przeżuwanie” określonych treści, często pojawiających się bez wyraźnej przyczyny. Według Nolen-Hoeksemy (2000) 
myślenie ruminacyjne to pasywna i utrzymująca się koncentracja uwagi na odczuwanych negatywnych emocjach. Takie rozumienie ruminacji powiązane jest przede wszystkim z występowaniem objawów patologii, głównie depresji i lęku. Natomiast Calhoun i Tedeschi (1998) traktują ruminowanie jako proces obejmujący nawracające myśli dotyczące zdarzenia traumatycznego, które mogą mieć charakter negatywny, lecz również pozytywny i neutralny.

Warto zwrócić uwagę na pewne podobieństwa, ale także wskazać różnice między ruminacjami intruzywnymi a intruzjami, traktowanymi jako objaw PTSD. Jak wskazują Ehring i Ehlers (2014), intruzje odnoszą się, podobnie jak ruminacje, do powracających myśli, obrazów i emocji związanych z traumą, lecz trwają na ogół krótko i odzwierciedlają doświadczenia samego urazu. Tymczasem ruminacje są ujmowane jako ciąg myśli będących następstwem doświadczonego zdarzenia, ale o dłuższym czasie trwania.

Ruminacje pełnią istotną rolę zarówno dla negatywnych, jak i pozytywnych następstw doświadczonych zdarzeń traumatycznych. Ich znaczenie dla ponoszonych konsekwencji wiąże się z rozróżnieniem dwóch rodzajów ruminacji. Pierwszy z nich to ruminacje natrętne/intruzywne (intrusive ruminations). Są to automatycznie pojawiające się destrukcyjne myśli, których jednostka nie jest w stanie kontrolować i które nie są powiązane z próbami rozwiązania problemu. Sprzyjają one przede wszystkim pojawianiu się i podtrzymywaniu objawów stresu pourazowego (Cann i in., 2011; Ehlers, Clark, 2000; Ehring, Ehlers, 2014). Drugi rodzaj to ruminacje rozważne, refleksyjne (deliberate rumination), które mają charakter konstruktywny. Służą one przeanalizowaniu sytuacji w celu poszukiwania sposobów jej rozwiązania. Tego rodzaju ruminacje są traktowane jako czynnik sprzyjający pojawianiu się pozytywnych zmian potraumatycznych (Calhoun, Tedeschi, 2006; Calhoun i in., 2010; Cann i in., 2011; Taku i in., 2008).

Udział ruminacji w występowaniu pozytywnych zmian potraumatycznych jest jednak złożony. Opracowany przez amerykańskich badaczy (Calhoun, Tedeschi, 2006; Calhoun i in., 2010; por. także: Ogińska-Bulik, 2016a) zrewidowany model potraumatycznego wzrostu wskazuje, że bezpośrednim następstwem doświadczonego zdarzenia są ruminacje o charakterze intruzywnym (nieintencjonalnym). Tego typu ruminowanie prowadzi początkowo do rozwoju i podtrzymywania objawów PTSD. Później jednak, wraz z poprawą stanu psychicznego, ruminacje intruzywne zmieniają się w ruminacje refleksyjne (intencjonalne). Ten rodzaj ruminacji pozwala jednostce na przynajmniej częściowe odzyskanie kontroli nad sytuacją i poszukiwanie sposobów poradzenia sobie z nią. Ruminacje natrętne mogą służyć podtrzymywaniu dalszej aktywności poznawczej jednostki i torować drogę ruminacjom refleksyjnym (Calhoun i in., 2010). Oznaczałoby to, że obydwa rodzaje ruminacji pełnią istotną rolę $\mathrm{w}$ występowaniu pozytywnych zmian potraumatycznych. Procesowi przekształcania się ruminacji intruzywnych w refleksyjne u osób, które doświadczyły traumy, sprzyja prowadzona terapia, zwłaszcza poznawczo-behawioralna, ale proces ten może się także odbywać samoistnie. 
W Polsce badania dotyczące związku ruminowania o doświadczonym zdarzeniu z występowaniem pozytywnych następstw doświadczonej traumy wciąż należą do rzadkości. Te dostępne dostarczyły niejednoznacznych wyników dotyczących związku między zmiennymi. Predykcyjną rolę ruminacji refleksyjnych dla pozytywnych zmian potraumatycznych wykazano wśród chorych onkologicznie (Ogińska-Bulik, 2016b), a także rodziców opiekujących się dziećmi chorymi nowotworowo (Ogińska-Bulik, Ciechomska, 2016). Ten rodzaj ruminacji okazał się także predyktorem - choć słabym - wzrostu po traumie u kobiet, które doznały przemocy domowej (Ogińska-Bulik, 2016c).

W badaniach ratowników medycznych (Ogińska-Bulik, Juczyński, 2016) ujawniono, że predyktorami PTG były zarówno ruminacje intruzywne, jak i refleksyjne, ale moc wyjaśniająca tych drugich była znacząco większa. Z kolei badania przeprowadzone wśród osób zakażonych HIV (Ogińska-Bulik, 2016d) nie wykazały znaczenia ruminacji w procesie występowania pozytywnych zmian potraumatycznych. Ujawnione niejednoznaczności skłaniają do dalszych eksploracji w tym zakresie.

\section{CEL I METODA BADAŃ}

Podjęte badania miały na celu ustalenie związku między ruminowaniem, odnoszącym się do doświadczonych zdarzeń o charakterze traumatycznym, a występowaniem pozytywnych następstw tych zdarzeń, ujawnianych w postaci potraumatycznego wzrostu. Poszukiwano odpowiedzi na następujące pytania badawcze:

1) W jakim stopniu w grupie ratowników medycznych, którzy doświadczyli zdarzeń traumatycznych w związku z wykonywaną pracą, występuje potraumatyczny wzrost $\mathrm{i}$ jakie jest nasilenie ruminacji związanych z doświadczonymi wydarzeniami?

2) Czy ruminacje wiążą się z nasileniem pozytywnych następstw tych zdarzeń?

3) Który z dwóch rodzajów ruminacji (intruzywne, refleksyjne) pozwala na przewidywanie wystąpienia wzrostu po traumie?

Przyjęty model badań odwołuje się do koncepcji Calhouna i Tedeschiego (Calhoun, Tedeschi, 2006; Calhoun i in., 2010), zakładającej istotny udział ruminacji w występowaniu pozytywnych zmian potraumatycznych. Założono, że obydwa rodzaje ruminacji, tj. tak natrętne, jak i refleksyjne, będą dodatnio powiązane z poziomem potraumatycznego wzrostu, przy czym silniejsze związki będą dotyczyć ruminacji refleksyjnych. W analizach uwzględniono także wiek i płeć badanych.

Badaniom poddano 120 ratowników medycznych z terenu woj. łódzkiego. Badania odbywały się w miejscu pracy za zgodą przełożonych i miały charakter anonimowy i dobrowolny ${ }^{1}$. Do analizy wyników zakwalifikowano dane uzyskane od 85 ratowników (70,8\% ogółu badanych), tj. 55 mężczyzn $(64,7 \%)$ oraz 30 kobiet $(35,3 \%)$, którzy w związku z pełnieniem swoich obowiązków służbowych

\footnotetext{
${ }^{1}$ Badania zostały przeprowadzone w ramach seminarium magisterskiego.
} 
potwierdzili wystąpienie w ostatnich 5 latach przynajmniej jednego zdarzenia traumatycznego, związanego ze śmiercią lub zagrożeniem życia, bądź poważnym zranieniem, zagrożeniem fizycznej integralności własnej czy innych ludzi. Wiek badanych mieścił się $\mathrm{w}$ granicach 25-61 lat $(\mathrm{M}=38,07, \mathrm{SD}=9,61)$.

W badaniach wykorzystano ankietę zawierającą pytania o wiek, płeć, a także o to, czy respondenci doświadczyli zdarzeń traumatycznych w związku z wykonywaną pracą i jakie to były zdarzenia. Ponadto zastosowano dwa standardowe narzędzia pomiaru, tj. Inwentarz Potraumatycznego Rozwoju oraz Inwentarz Ruminacji o Negatywnym Zdarzeniu.

Inwentarz Potraumatycznego Rozwoju - IPR (Posttraumatic Growth Inventory - PTGI), którego autorami są Tedeschi i Calhoun (1996), zaadaptowany do warunków polskich przez Ogińską-Bulik i Juczyńskiego (2010), składa się z 21 stwierdzeń opisujących różne pozytywne zmiany zaistniałe w wyniku doświadczonego wydarzenia traumatycznego. Badana osoba ustosunkowuje się do podanych stwierdzeń, wybierając odpowiedzi od „nie doświadczyłem tej zmiany” (0 pkt), do „doświadczyłem tej zmiany w bardzo dużym stopniu” (5 pkt). W polskiej wersji, poza ogólnym wskaźnikiem nasilenia PTG, inwentarz mierzy cztery czynniki składające się na wzrost po traumie, tj. 1) zmiany w percepcji siebie, 2) zmiany w relacjach z innymi, 3) większe docenianie życia i 4) zmiany duchowe. Wynik ogólny jest sumą czterech wymienionych czynników. Wskaźniki rzetelności są porównywalne z wersją oryginalną (alfa Cronbacha $=0,93$ ).

Inwentarz Ruminacji o Negatywnym Zdarzeniu (IRoNZ) jest polską adaptacją (Ogińska-Bulik, Juczyński, 2015) amerykańskiego narzędzia Event Related Rumination Inventory (ERRI), autorstwa Canna i wsp. (2011). Zawiera dwie podskale, każda po 10 stwierdzeń. Pierwsza odnosi się do ruminacji intruzywnych (natrętnych, automatycznych), które mają charakter niekontrolowany (np. „Myślałem o tym zdarzeniu, nawet kiedy nie chciałem o nim myśleć"), druga - refleksyjnych (celowych) (np. „Zastanawiałem się, czy to zdarzenie miało dla mnie jakieś znaczenie"). Osoba badana dokonuje oceny na 4-stopniowej skali typu Likerta. Wyniki oblicza się oddzielnie dla każdej z podskal. Inwentarz charakteryzuje się bardzo dobrymi właściwościami psychometrycznymi (alfa Cronbacha dla ruminacji intruzywnych wynosi 0,96 , a dla refleksyjnych 0,92 ).

\section{WYNIKI BADAŃ}

Obliczenia wykonano przy pomocy programu STATISTICA. Do analiz wykorzystano testy parametryczne, tj. test t-Studenta dla porównania różnic między średnimi oraz współczynniki korelacji Pearsona do ustalenia związku między zmiennymi. Ponadto wykorzystano analizę regresji wielokrotnej do wyznaczenia predyktorów PTG $^{2}$.

${ }^{2}$ Wyniki badań przedstawiono na Ogólnopolskiej Konferencji Naukowej Rodzina - Praca pt. „Kobiety i mężczyźni w rolach rodzinnych i zawodowych”, Łódź, 28-29.11.2016. 
Najczęściej wymieniane przez badanych ratowników medycznych wydarzenia wiązały się z niesieniem pomocy rannym $\mathrm{w}$ poważnych wypadkach drogowych, ofiarom wybuchu gazu oraz udzielaniem pierwszej pomocy dzieciom-ofiarom przemocy. Uzyskane średnie analizowanych zmiennych, a także zakresy uzyskanych wyników, odchylenia standardowe, skośność i kurtozy prezentuje tabela 1.

Tabela 1. Średnie analizowanych zmiennych

\begin{tabular}{|l|r|r|c|c|c|}
\hline \multicolumn{1}{|c|}{ Analizowane zmienne } & $\mathrm{M}$ & $\mathrm{SD}$ & Zakres & Skośność & Kurtoza \\
\hline Potraumatyczny wzrost - ogółem & 39,67 & 19,61 & $1-90$ & 0,07 & $-0,17$ \\
\hline Cz. 1. Zmiany w percepcji siebie & 17,42 & 9,14 & $1-45$ & 0,14 & 0,14 \\
\hline Cz. 2. Zmiany w relacjach z innymi & 13,32 & 7,76 & $0-28$ & 0,01 & $-0,93$ \\
\hline Cz. 3. Docenianie życia & 7,20 & 3,61 & $0-14$ & $-0,16$ & $-0,72$ \\
\hline Cz. 4. Zmiany duchowe & 1,73 & 2,23 & $0-8$ & 1,30 & 0,79 \\
\hline Ruminacje intruzywne & 8,65 & 6,61 & $0-28$ & 0,60 & $-0,14$ \\
\hline Ruminacje refleksyjne & 10,68 & 6,34 & $0-25$ & $-0,06$ & $-1,02$ \\
\hline
\end{tabular}

Źródło: opracowanie własne.

Uzyskana średnia potraumatycznego wzrostu, według norm opracowanych dla IPR (Ogińska-Bulik, Juczyński, 2010), mieści się na granicy 3-4 stena. Oznacza więc wynik niski. Skośność dla tej zmiennej ma charakter dodatni, co oznacza, że występuje lekka przewaga wyników niskich. Natomiast w przypadku pozytywnych zmian w sferze duchowej zaznacza się wyraźna przewaga wyników niskich (rozkład odbiega od normalnego). Kurtoza dla ogólnego wyniku potraumatycznego wzrostu jest ujemna, co wskazuje, że wartości tej zmiennej są skoncentrowane wokół średniej w nieco mniejszym stopniu niż w rozkładzie normalnym (rozkład platykurtyczny).

Istotnie większe zmiany $(\mathrm{p}<0,01)$ zaobserwowano $\mathrm{w}$ docenianiu życia $(\mathrm{M}=2,4, \mathrm{SD}=1,22)$ niż w pozostałych obszarach wzrostu po traumie (zmiany w percepcji siebie: $\mathrm{M}=1,93, \mathrm{SD}=1,01$; zmiany w relacjach $\mathrm{z}$ innymi: $\mathrm{M}=1,0$, $\mathrm{SD}=1,10$; zmiany w sferze duchowej: $\mathrm{M}=0,86, \mathrm{SD}=1,15$ ).

Poziom potraumatycznego wzrostu nie wiąże się w sposób istotny statystycznie $\mathrm{z}$ wiekiem $(\mathrm{r}=0,16)$ ani $\mathrm{z}$ płcią badanych ratowników medycznych (mężczyźni: $\mathrm{M}=38,42, \mathrm{SD}=21,66$; kobiety: $\mathrm{M}=41,97, \mathrm{SD}=15,22, \mathrm{t}(83)=-0,79)$.

Nasilenie ujawnionych przez ratowników ruminacji, tak intruzywnych, jak i refleksyjnych, jest niskie. Uzyskane średnie, według norm opracowanych dla IRoNZ (Ogińska-Bulik, Juczyński, 2015), uwzględniając obydwa rodzaje ruminacji oraz płeć, odpowiadają wartości 4 stena. Skośność dla ruminacji intruzywnych jest dodatnia, a kurtoza ujemna. $Z$ kolei w przypadku ruminacji refleksyjnych zarówno skośność, jak i kurtoza przybierają wartości ujemne.

W obydwu rodzajach ruminacji mężczyźni wykazują niższy ich poziom w porównaniu z kobietami (natrętne: $\mathrm{M}=7,00, \mathrm{SD}=6,06 \mathrm{i} \mathrm{M}=11,67, \mathrm{SD}=6,62$, 
$\mathrm{t}(83)=-3,28, \mathrm{p}<0,01$; refleksyjne: $\mathrm{M}=9,60, \mathrm{SD}=5,82$ i $12,67, \mathrm{SD}=6,87$, $\mathrm{t}(83)=-2,17, \mathrm{p}<0,05)$. Wiek nie wiąże się $\mathrm{z}$ nasileniem ruminacji, tak natrętnych $(\mathrm{r}=-0,04)$, jak i refleksyjnych $(\mathrm{r}=0,08)$.

Celem uzyskania odpowiedzi na pytanie, czy ruminacje, odnoszące się do doświadczonych zdarzeń o charakterze traumatycznym, wiążą się z nasileniem wzrostu po traumie, obliczono współczynniki korelacji (tab. 2).

Tabela 2. Współczynniki korelacji między ruminacjami a potraumatycznym wzrostem

\begin{tabular}{|l|c|c|}
\hline \multicolumn{1}{|c|}{ Potraumatyczny wzrost } & Ruminacje natrętne & Ruminacje refleksyjne \\
\hline Ogółem & 0,17 & $0,40^{* * *}$ \\
\hline Cz. 1. Zmiany w percepcji siebie & 0,18 & $0,29^{* *}$ \\
\hline Cz. 2. Zmiany w relacjach z innymi & 0,10 & $0,41^{* * *}$ \\
\hline Cz. 3. Docenianie życia & $0,22^{*}$ & $0,39^{* * *}$ \\
\hline Cz. 4. Zmiany duchowe & 0,09 & $0,29^{* *}$ \\
\hline
\end{tabular}

${ }^{* * *} \mathrm{p}<0,001,{ }^{* *} \mathrm{p}<0,01,{ }^{*} \mathrm{p}<0,05$

Źródło: opracowanie własne.

Uzyskane współczynniki korelacji wskazują na dodatnie związki ruminacji refleksyjnych ze wzrostem po traumie. Ruminacje te są silniej powiązane ze zmianami w relacjach z innymi i docenianiem życia, słabiej zaś ze zmianami w percepcji siebie i sferze duchowej. Ruminacje intruzywne nie korelują w sposób istotny statystycznie z poziomem potraumatycznego wzrostu. Jedyny istotny związek - choć słaby - ruminacji natrętnych odnosi się do doceniania życia.

Stwierdzone związki między ruminacjami a pozytywnymi konsekwencjami doświadczonej traumy czynią zasadne poszukiwanie odpowiedzi na kolejne pytanie badawcze, tj. o to, który rodzaj ruminacji pozwala na przewidywanie wystąpienia pozytywnych zmian potraumatycznych. Do modelu (regresja krokowa, postępująca) wprowadzono dwie zmienne objaśniające, tj. ruminacje intruzywne i refleksyjne. Zmienną objaśnianą był potraumatyczny wzrost (tab. 3), a także poszczególne jego obszary.

Tabela 3. Predyktory PTG (wynik ogólny)

\begin{tabular}{|l|c|c|c|c|c|c|}
\hline \multicolumn{1}{|c|}{ Predyktory } & Beta & Błąd Beta & B & Błąd B & $\mathrm{t}(81)$ & $\mathrm{p}<$ \\
\hline Wartość stała & & & 26,35 & 3,85 & 6,84 & 0,001 \\
\hline Ruminacje refleksyjne & 0,40 & 0,10 & 1,24 & 0,31 & 4,02 & 0,001 \\
\hline
\end{tabular}

$\mathrm{R}=0,40 ; \mathrm{R}^{2}=0,16$

Beta - standaryzowany współczynnik regresji; B - niestandaryzowany współczynnik regresji; $\mathrm{t}$ - wartość testu t; $\mathrm{p}$ - prawdopodobieństwo w teście; $\mathrm{R}$ - współczynnik korelacji; $\mathrm{R}^{2}$ - współczynnik determinacji

Źródło: opracowanie własne. 
Predyktorem pozytywnych zmian, ujawnianych w postaci ogólnego wskaźnika potraumatycznego wzrostu, okazało się ruminowanie refleksyjne $($ Beta $=$ $\left.0,29, R^{2}=0,08\right)$. Oznacza to, że koncentracja jednostki na myślach, obrazach i wrażeniach związanych z doświadczoną traumą, celem poszukiwania sposobów poradzenia sobie z nią, może prowadzić do wystąpienia pozytywnych zmian potraumatycznych. Należy podkreślić, że ten rodzaj ruminacji wyjaśnia jednak niewielki odsetek (8\%) wariancji zmiennej zależnej. Oznacza to, że pozostałe $92 \%$ wyjaśniane jest innymi czynnikami, nieuwzględnionymi w badaniu.

Ruminacje refleksyjne okazały się również predyktorem pozytywnych zmian we wszystkich obszarach wzrostu po traumie. Największy udział mają one w występowaniu pozytywnych zmian $\mathrm{w}$ relacjach $\mathrm{z}$ innymi $\left(\right.$ Beta $\left.=0,54, \mathrm{R}^{2}=0,18\right)$ i docenianiu życia $\left(\right.$ Beta $\left.=0,39, \mathrm{R}^{2}=0,15\right)$, wyjaśniając odpowiednio $18 \%$ i $15 \%$ wariancji zmiennych zależnych. Mniejszy ich udział dotyczy przewidywania pozytywnych zmian w percepcji siebie $\left(\right.$ Beta $\left.=0,29, \mathrm{R}^{2}=0,08\right)$ i sferze duchowej $\left(\right.$ Beta $\left.=0,29, \mathrm{R}^{2}=0,09\right)$, tj. $8 \%$ i $9 \%$.

\section{PODSUMOWANIE I DYSKUSJA WYNIKÓW}

Zdecydowana większość (70,8\%) spośród 120 objętych badaniami ratowników medycznych przyznała, że doświadczyła zdarzenia traumatycznego w związku z pełnieniem obowiązków służbowych w ciągu ostatnich 5 lat. Badani ratownicy dostrzegli u siebie pozytywne zmiany w wyniku przeżytych doświadczeń, jednakże poziom tych zmian jest ogólnie niski. Na niskie nasilenie wzrostu po traumie wśród pracowników służb ratowniczych wskazują również inne badania (Ogińska-Bulik, 2015; Ogińska-Bulik, Juczyński, 2010, 2016). Może to między innymi wiązać się z faktem, że pracownicy służb ratowniczych są (a przynajmniej powinni być) przygotowani na wystąpienie zdarzeń traumatycznych i z reguły dobrze sobie z nimi radzą. Zdaje się to potwierdzać stosunkowo niski (przynajmniej w warunkach polskich) - wynoszący 5\% - odsetek pracowników pogotowia ratunkowego ujawniających PTSD (Koniarek, 1997). Z kolei wystąpienie negatywnych następstw doświadczonych zdarzeń jest traktowane jako warunek konieczny pojawienia się zmian o charakterze pozytywnym.

Uzyskane wyniki badań wskazują również, że badani ratownicy w niewielkim stopniu angażują się poznawczo w przetwarzanie traumy, o czym świadczy niskie nasilenie ruminacji, tak intruzywnych, jak i refleksyjnych. Można przypuszczać, że doświadczane zdarzenia (występujące niemal codziennie) nie stanowią dla nich istotnego wyzwania, które wiązałoby się z naruszeniem posiadanych schematów poznawczych dotyczących świata i własnej osoby.

Rezultaty przeprowadzonych badań potwierdziły, że ruminowanie o doświadczonych zdarzeniach traumatycznych, wynikających z pełnienia obowiązków służbowych, odgrywa istotną - choć raczej słabą - rolę w występowaniu 
pozytywnych ich następstw i dotyczy jedynie ruminacji refleksyjnych. Ruminowanie refleksyjne ma większe znaczenie w przewidywaniu wystąpienia pozytywnych zmian w relacjach z innymi i docenianiu życia niż pozostałych dwóch obszarów potraumatycznego wzrostu, tj. zmian w percepcji siebie i sferze duchowej.

Uzyskane wyniki badań, wskazujące na istotną rolę ruminowania refleksyjnego, są w znacznym stopniu zgodne $\mathrm{z}$ rezultatami innych badań, przeprowadzonych przede wszystkim wśród studentów, którzy doświadczyli różnych negatywnych zdarzeń życiowych (Cann i in., 2011; Su, Chen, 2015; Taku i in., 2008). Ruminacje refleksyjne, polegające na świadomym przebudowywaniu reprezentacji poznawczych ważnych aspektów życia człowieka, odgrywają kluczową rolę $\mathrm{w}$ procesie radzenia sobie $\mathrm{z}$ traumą. Sprzyjają one wprowadzaniu zmian w sposobie widzenia świata, polegających na jego głębszym zrozumieniu, przede wszystkim poszukiwaniu sensu doświadczonych sytuacji i nadawaniu im znaczenia. Kształtują także przekonanie jednostki o własnych zdolnościach do radzenia sobie, co w efekcie prowadzi do zmian wzrostowych.

Uzyskane rezultaty badań nie potwierdziły przewidywanego pozytywnego związku między ruminowaniem intruzywnym a występowaniem pozytywnych zmian potraumatycznych. Może to sugerować, że u badanych ratowników medycznych w wyniku doświadczonych zdarzeń traumatycznych wystąpił niepełny proces przetwarzania traumy, na co wskazuje niskie nasilenie ruminacji, zwłaszcza natrętnych, co w efekcie mogło prowadzić do niskiego poziomu wzrostu po traumie. Jest także prawdopodobne, że ruminowanie intruzywne sprzyjałoby występowaniu objawów PTSD, czego nie analizowano w podjętych badaniach. Wskazują na to badania przeprowadzone $\mathrm{w}$ innej grupie ratowników medycznych, w której ujawniono związek między ruminacjami intruzywnymi a objawami PTSD (Ogińska-Bulik, Juczyński, 2016).

Warto zwrócić uwagę, że nie wszyscy badacze potwierdzają istotną rolę procesów poznawczych i własnej refleksyjności w pojawianiu się pozytywnych zmian potraumatycznych. Dla przykładu Salsman i in. (2009), w badaniach obejmujących chorych na nowotwór jelita grubego, ujawnili brak związku między ruminowaniem, tak intruzywnym jak i refleksyjnym, a występowaniem PTG.

$\mathrm{W}$ procesie radzenia sobie $\mathrm{z}$ traumą zwraca się także uwagę na znaczenie innych czynników, które mogą sprzyjać wystąpieniu pozytywnych zmian potraumatycznych. Podkreśla się rolę posiadanych przez jednostkę zasobów osobistych, stosowanych strategii radzenia sobie, a także uzyskiwanego wsparcia społecznego (Ogińska-Bulik, 2015). Czynniki te mogą również wiązać się ze skłonnością do ruminowania. Teza ta wymagałaby jednak potwierdzenia.

Warto dodać, że na ogół ruminacjom przypisuje się negatywną konotację, podkreślając ich destrukcyjne znaczenie dla funkcjonowania człowieka. „Przeżuwanie" treści o zabarwieniu negatywnym, związanych z doświadczonymi traumatycznymi zdarzeniami, prowadzi zwykle do obniżenia nastroju, objawów depresji i nasilenia poczucia stresu (Nolen-Hoeksema, 2000; Watkins, 2004). Warto więc 
zachęcać osoby, które doświadczyły traumy, do zmiany sposobu ruminowania z natrętnego na refleksyjny. Należy tu jednak zachować pewną ostrożność, gdyż, jak wskazują Foa i wsp. (2014), w niektórych przypadkach zachęcanie do ujawniania informacji o traumie, bez uwzględnienia zasad wentylowania emocji i etapów przepracowania traumy, może przynieść skutki przeciwne do oczekiwanych.

Przeprowadzone badania wiążą się z pewnymi ograniczeniami. Oceny pozytywnych skutków doświadczonych zdarzeń traumatycznych dokonano za pomocą samoopisu. W badanej grupie ratowników medycznych, reprezentującej tylko jedno województwo, nie analizowano znaczenia czasu, w jakim miało miejsce zdarzenie traumatyczne. Przyjęto jedynie, że występowało ono w ostatnich pięciu latach. W badaniach skoncentrowano się na zdarzeniach traumatycznych związanych z pełnieniem obowiązków służbowych. Nie analizowano osobistych doświadczeń traumatycznych, które mogły wystąpić - przynajmniej u niektórych badanych - i wpływać na pojawianie się pozytywnych zmian potraumatycznych. Ponadto, badania miały charakter przekrojowy, co nie upoważnia w sposób jednoznaczny do wnioskowania o zależnościach przyczynowo-skutkowych.

Pomimo przedstawionych ograniczeń uzyskane wyniki badań wnoszą nowe treści w zakresie związku między podejmowaną w obliczu traumy aktywnością poznawczą jednostki a występowaniem pozytywnych zmian potraumatycznych. Uzyskane wyniki mogą stanowić inspirację do dalszych poszukiwań. W kolejnych badaniach warto byłoby uwzględnić także inne formy aktywności poznawczej jednostki podejmowanej w wyniku doświadczonej traumy, jak np. zmiana podstawowych założeń wobec świata i własnej osoby czy przetwarzanie emocjonalne. Bardziej dokładne ustalenie roli ruminowania o doświadczonych zdarzeniach, w procesie pojawiania się pozytywnych ich następstw, wymagałoby przeprowadzenia badań o charakterze podłużnym, z uwzględnieniem oceny ruminacji występujących bezpośrednio po wydarzeniu, jak i aktualnych.

\section{BIBLIOGRAFIA}

Andersen H. S., Christensen A. K., Peterson G. O. (2007). Posttraumatic stress reaction amongst rescue workers after a major rail accident. Anxiety Research, 4 (3), 245-251

APA (1994). Diagnostic and statistical manual of mental disorders - Fourth edition - DSM-IV. Washington, DC

APA (2013). Diagnostic and statistical manual of mental disorders. Fifth edition - DSM-5, http:// dx.doi.org/10.1176/appi.books.9780890425596

Calhoun L. G., Tedeschi R. G. (1998). Posttraumatic growth: Future directions. W: R. G. Tedeschi, C. L. Park, L. G. Calhoun (eds.), Posttraumatic growth: Positive changes in the aftermath of crisis (s. 215-238). New Jersey: Lawrence Erlbaum Associates

Calhoun L. G., Tedeschi R. G. (2006). The foundations of posttraumatic growth: An expanded framework. W: L. G. Calhoun, R. G. Tedeschi (eds.), Handbook of posttraumatic growth (s. 1-23). New Jersey: Lawrence Erlbaum Associates 
Calhoun L. G., Cann A., Tedeschi R. G. (2010). The posttraumatic growth model: Sociocultural considerations. W: T. Weiss, R. Berger (eds.), Posttraumatic growth and culturally competent practice: Lessons learned from around the globe (s. 1-14). New Jersey: John Wiley \& Sons

Cann A., Calhoun L. G., Tedeschi R. G., Triplett K. N., Vishnevsky T., Lindstrom C. M. (2011). Assessing posttraumatic cognitive processes: The Event Related Rumination Inventory. Anxiety, Stress and Coping, 24 (2), 137-156

Clohessy S., Ehlers A. (1990). PTSD symptoms, response to intrusive memories and coping in ambulance service workers. British Journal of Clinical Psychology, 38, 251-265

Dudek B. (2003). Zaburzenie po stresie traumatycznym. Gdańsk: Gdańskie Wydawnictwo Psychologiczne

Ehlers A., Clark D. M. (2000). A cognitive model of posttraumatic stress disorder. Behaviour Research and Therapy, 38 (4), 319-345

Ehring T., Ehlers A. (2014). Does rumination mediate the relationship between emotion regulation ability and posttraumatic stress disorder? Psychotraumatology, 26 (5), doi.org/10.3402/ ejpt.v.523547

Foa E. B., Chrestman K. R., Gilboa-Schechtman E. (2014). Przedtużona ekspozycja w terapii PTSD nastolatków. Emocjonalne przetwarzanie traumatycznych doświadczeń. Gdańsk: Gdańskie Wydawnictwo Psychologiczne

Gray L. (2008). Emergency service providers'organizational climate and its role in the development of traumatic stress and posttraumatic growth. Doctoral dissertation, pozyskano z ProQuest Dissertations and Theses Database (AAT 47114), http://www.proquest.com/products-services/ pqdtglobal.html

Jonsson A., Segesten K., Mattsson B. (2003). Post-traumatic stress among Swedish ambulance personnel. Emergency Medical Journal, 20 (1), 79-84

Kirby R., Shakespeare-Finch J., Palk G. (2011). Adaptive and maladaptive coping strategies predict posttrauma outcomes in ambulance personnel. Traumatology, 17 (4), 25-34

Koniarek J. (1997). Występowanie zaburzeń po stresie urazowym wśród pracowników Pogotowia Ratunkowego w Łodzi (raport z badań). Łódź: Wydawnictwo Instytutu Medycyny Pracy im. prof. J. Nofera

Lis-Turlejska M. (2009). Zdarzenia traumatyczne - sposoby definiowania, pomiar i rozpowszechnienie. W: J. Strelau, B. Zawadzki, M. Kaczmarek (red.), Konsekwencje psychiczne traumy. Uwarunkowania i terapia (s. 15-33). Warszawa: Wydawnictwo Naukowe SCHOLAR

Melersky J. (2008). Trauma, coping, and functioning in a sample of rescue workers 34 to 39 months after September $11^{\text {th }}$. Doctoral dissertations, pozyskano z ProQuest Dissertations and Theses Database (AAT 3283333), http://www.proquest.com/products-services/pqdtglobal.html

Nolen-Hoeksema S. (2000). The role of rumination in depressive disorders and mixed depressive / anxiety symptoms. Journal of Abnormal Psychology, 109 (3), 504-511

Ogińska-Bulik N. (2015). Dwa oblicza traumy - negatywne i pozytywne skutki zdarzeń traumatycznych u pracowników stużb ratowniczych. Warszawa: Wydawnictwo Difin

Ogińska-Bulik N. (2016a). Negatywne i pozytywne następstwa doświadczonej traumy - rola ruminacji. Psychiatria i Psychologia Kliniczna, 16 (3), 182-187

Ogińska-Bulik N. (2016b). Rola ruminacji w występowaniu pozytywnych zmian potraumatycznych u osób zmagających się z chorobami nowotworowymi. Psychoonkologia, 20 (1), 1-8. doi: 10.5114 /pson.2015.55305

Ogińska-Bulik N. (2016c). Ruminacje a skutki traumy u kobiet doświadczających przemocy w rodzinie/Ruminations and effects of trauma in women experiencing domestic violence. Roczniki Psychologiczne, 19 (4), 627-658

Ogińska-Bulik N. (2016d). Ruminacje a negatywne i pozytywne skutki traumy u zakażonych HIV. Psychiatria, 13 (1), 8-16 
Ogińska-Bulik N., Ciechomska M. (2016). Posttraumatic growth of parents struggling with cancer disease of their child - the role of rumination/Wzrost po traumie u rodziców zmagających się z chorobą nowotworową dziecka - rola ruminacji. Postępy Psychiatrii i Neurologii, 25 (2), 99-110, http://dx.doi.org/10.1016/j.pin.2016.05.002

Ogińska-Bulik N., Juczyński Z. (2010). Rozwój potraumatyczny - charakterystyka i pomiar. Psychiatria, 7 (4), 129-142

Ogińska N., Juczyński Z. (2015). Inwentarz Ruminacji o Negatywnym Zdarzeniu - polska adaptacja the Event Related Rumination Inventory. Przeglad Psychologiczny, 58 (3), 383-400

Ogińska-Bulik N., Juczyński Z. (2016). Ruminacje a negatywne i pozytywne następstwa doświadczonych zdarzeń traumatycznych u ratowników medycznych. Medycyna Pracy, 67 (2), 201-211

Regehr C., Goldberg G., Hughes J. (2002). Exposure to human tragedy, empathy and trauma in ambulance paramedics. American Journal of Orthopsychiatry, 72 (4), 505-513

Salsman J. M., Segerstrom S. C., Brechting E. H., Carlson C. R., Andrykowski M. A. (2009). Posttraumatic growth and posttraumatic stress disorder symptomatology among colocteral cancer survivors: A 3 month longitudinal examination of cognitive processing. Psychooncology, 18, $30-41$

Steuden S., Janowski K. (2016). Trauma - kontrowersje wokół pojęcia, diagnoza, następstwa, implikacje praktyczne. Roczniki Psychologiczne, XIX (3), 549-565

Su Y. J., Chen S. H. (2015). Emerging posttraumatic growth: A prospective study with pre- and posttrauma psychological predictors. Psychological Trauma: Theory, Research, Practice, and Policy, 7 (2), 103-111, http://dx.doi.org/10.1037/tra0000008

Tedeschi R. G., Calhoun, L. G. (1996). The Post-Traumatic Growth Inventory: Measuring the positive legacy of trauma. Journal of Traumatic Stress, 9 (3), 455-471

Tedeschi R. G., Calhoun L. G. (2004). Posttraumatic growth: Conceptual foundations and empirical evidence. Psychological Inquiry, 15, 1-8

Taku K., Calhoun L. G., Cann A., Tedeschi R. G. (2008). The role of rumination in the coexistence of distress and posttraumatic growth among bereaved Japanese university students. Death Studies, 32, 428-444

Watkins E. (2004). Adaptive and maladaptive ruminative self-focus during emotional processing. Behaviour Research and Therapy, 42 (9), 1037-1052

NinA OGIŃSKA-BuLIK

\title{
RUMINATIONS AND POSTTRAUMATIC GROWTH AMONG MEDICAL RESCUE WORKERS
}

\begin{abstract}
Emergency service workers are exposed to experience traumatic events related to the nature of their work. The study aimed to identify the role of ruminations in occurrence of posttraumatic positive changes. The research was conducted in a group of 120 medical rescue workers, of whom 85 (55 men and 30 women) confirmed that they experienced at least one traumatic event in the context of their work in the last 5 years. The age of the participants ranged from 25 to 61 years $(\mathrm{M}=38.07 ; \mathrm{SD}=9.61)$. Polish versions of standardized tools were used: the Posttraumatic Growth Inventory - PTGI and the Event Related Rumination Inventory - ERRI. The participants revealed a low level of posttraumatic growth and low intensity of ruminations, both intrusive and deliberate ones. Among the two types of the analyzed ruminations only deliberate ones proved to be a predictor
\end{abstract}


of posttraumatic growth and all its factors. Deliberate ruminations play an essential role in the occurrence of positive outcomes of an experienced trauma.

Keywords: traumatic events, posttraumatic growth, ruminations, medical rescue workers. 